\title{
RANCANG BANGUN GAME FIGHTING PEWAYANGAN BAHURAKSA ARENA
}

\author{
Aisy Muhammad R ${ }^{1}$, Dyah Ayu Irawati ${ }^{2}$, Dr.Eng. Faisal Rahutomo ${ }^{3}$ \\ 1,2,3 Jurusan Teknologi Informasi, Program Studi Teknik Informatika, Politeknik Negeri Malang \\ Email : aisymuhammad@gmail.com ${ }^{1}$, dyah.ayu.irawati@gmail.com ${ }^{2}$, faisal_rahutomo@polinema.ac.id ${ }^{3}$
}

\begin{abstract}
Abstrak
Wayang adalah salah satu pertunjukkan yang dimiliki oleh Indonesia, dan salah satu kisah wayang yang sering digunakan adalah "Mahabharata". Menceritakan konflik antara Pandawa dan Kurawa, dari kedua belah pihak memiliki prajurit ataupun ksatria yang memiliki kesaktian dan cara bertarung sendiri. Sehingga sangat cocok untuk di kembangkan menjadi sebuah game fighting. Game sangat populer di semua kalangan baik dari dewasa hingga anak kecil, terutama di platform mobile, karena game mobile bisa dimainkan dimana saja. Game fighting sendiri adalah salah satu genre game yang dimana seorang pemain mengendalikan salah satu karakter dan bertarung dengan jarak yang dekat dengan seorang lawan. game ini di buat dengan menggunakan metode $\mathrm{N}$ Gram untuk menghasilkan kecerdasan buatan yang dapat menentukan pergerakan lawan atau yang di sebut dengan NPC(Non-Player Character). N-gram adalah metode untuk memprediksi gerakan pemain, pemain akan melakukan tindakan seperti gerak maju, mundur, lompat, jongkok, menyerang 1 dan menyerang 2 kemudian kecerdasan buata. Sehingga metode N-gram sangat cocok untuk di implementasikan pada game bergenre fighting.
\end{abstract}

Kata Kunci : Game, Game fighting, Budaya Indonesia, Wayang, Kecerdasan buatan, Metode N-gram.

\section{Pendahuluan}

Pada era yang maju saat ini, game adalah salah satu media teknologi yang populer di kalangan masyarakat baik dari anak kecil maupun dewasa karena game dapat menghilangkan stress dan mengisi waktu luang. Game juga merupakan bentuk aplikasi edukatif, artinya bisa dijadikan sebagai media pembelajaran dimana prosesnya bisa dilakukan dengan konsep belajar sambil bermain dengan memanfaatkan sebuah kecerdasan buatan untuk membantu para pemain dan menghalangi pemain untuk mencapai tujuan pada game tersebut. Banyak sekali penerapan game sebagai media pembelajaran terutama pada game berlatar kebudayaan di setiap daerah dalam beberapa negara.

Indonesia adalah negara yang sangat dikenal dengan kebudayaannya, terutama kisah wayang yang ada di Indonesia seperti kisah "Mahabharata", penokohan karakter dan cerita wayang dapat memberikan gambaran kepada kita tentang makna kehidupan dan kita dapat mengambil pesan moral dari cerita tersebut.

Sayangnya pelestarian kebudayaan wayang di Indonesia sendiri mulai menghilang karena pengaruh dari budaya asing, masyarakat Indonesia lebih menyukai kebudayaan asing dan menerapkannya dalam kehidupan sehari-hari, karena mereka menggaggap kebudayaan asing lebih modern dan keren daripada budaya negara Indonesia.

Dari permasalahan tersebut, perlu dibangun sebuah game untuk mengenalkan kepada masyrakat luas tentang budaya dan karakter wayang yang menceritakan kisah Mahabarata dengan menggunakan format game fighting yang bisa menggunakan salah satu karakter dari pihak Pandawa ataupun Kurawa dalam game ini untuk bertarung mewakili antara kedua belah pihak, karakter pada kedua pihak ini memiliki kesaktian yang berbeda sehingga sangat menarik apabila dibuat versi pertarungan langsung dengan menggunakan kecerdasan buatan untuk menghalangi pemain untuk menang di setiap pertarungan.

\section{Landasan Teori}

\subsection{Game}

Game adalah permainan yang menggunakan interaksi dengan antarmuka pengguna melalui gambar yang dihasilkan oleh piranti elektronik. Permainan umumnya menyediakan sistem 
penghargaan misalnya skor yang dihitung berdasarkan tingkat keberhasilan yang dicapai dalam menyelesaikan tugas-tugas yang ada di dalam permainan.

Kata game pada awalnya merujuk pada piranti tampilan raster. Namun dengan semakin dipakainya istilah game, kini kata game dapat digunakan untuk menyebut permainan pada piranti tampilan apapun. Sistem elektronik yang digunakan untuk menjalankan permainan disebut platform, contohnya adalah PC dan Konsol.

\subsection{Game Fighting}

Game fighting adalah Genre game berjenis action game di mana pada layar karakter saling menyerang. Permainan ini biasanya fitur khusus bergerak yang dipicu menggunakan urutan cepat menekan tombol dan gerakan joystick. Permainan tradisional menunjukkan pejuang dari pandangan samping, bahkan sebagai genre itu telah berkembang dari dua dimensi (2D) untuk grafis tiga dimensi (3D).

Game fighting biasanya melibatkan tangan ke tangan pertempuran, tetapi juga akan menampilkan senjata jarak dekat. genre ini berbeda dari beat ' $\mathrm{em}$ up, lain genre aksi yang melibatkan pertempuran, dimana karakter pemain harus melawan

\subsection{Metode N-GRAM}

$\mathrm{N}$-gram banyak digunakan dalam berbagai teknik analis statistik dan juga prediksi Bahasa. Ngram di dalam game biasanya digunakan untuk action prediction. Salah satunya adalah game fighting, dimana kecerdasan buatan akan memprediksi gerakan selanjutnya dari player. Metode N-gram ini digunakan untuk mengambil rangkaian dari aksi player sejumlah rentetan aksi player secara berkelanjutan, dimana dalam game fighting aksi player adalah memukul, menendang bertahan, berjalan dan lain sebagainya. Di dalam Ngram terdapat :

\section{a. Windows Size}

Windows Size adalah banyak data yang digunakan untuk memprediksi gerakan player selanjutnya. Windows Size sendiri selalu bernilai n1. Jadi untuk 3-Gram maka adalah 2 sementara untuk 4-Gram Windows Sizenya 3 dan seterusnya. Memperbesar Windows Size pada awalnya memperakurat prediksi yang dilakukan namun juga jika semakin besar akan menurunkan keakuratan prediksi, Seperti pada gambar ini :

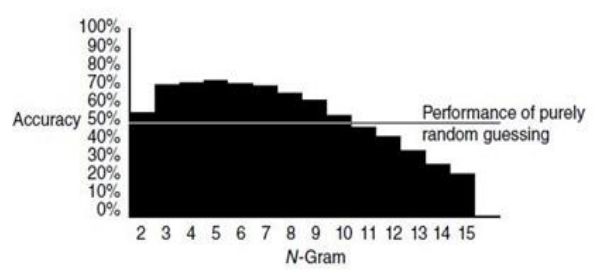

Gambar 1 Windows Size Pada Game Left Or Right

Gambar 1 diambil dari eksperimen yang dilakukan pada game Left or Right. Akurasi akan optimal jika N-nya diatara 2-9. Selebihnya nilai akurasinya justru malah dibawah jika melakukan random.

b. Sequence length

Sequence length adalah panjang urutan yang digunakan dalam N-gram. Pada awalnya prediksi tidak akan pernah akurat, karena belum adanya data yang masuk sehingga semua kemungkinan masih terbentuk, atau masih memiliki frekuensi yang masih terlalu kecil dan juga nilainya masih sama satu sama lain. Jika N-nya besar maka pembentukan pattern juga akan menjadi lama karena kombinasi pattern lebih banyak, sehingga akhirnya proses menuju prediksi yang optimal menjadi lamban.

\section{c. Memory Concerns}

Memory Concerns adalah banyaknya data yang disimpan dalam N-gram. Prediksi akan menjadi akurat apabila kecerdasan buatan menyimpan banyak data dari hasil aksi seorang player. Jadi kecerdasan buatan yang menyimpan 1000 data akan lebih akurat daripada menggunakan 100 data.

\subsection{Wayang}

Wayang adalah suatu seni berupa drama asli indonesia. Seni pertunjukan ini meliputi seni suara, seni musik, seni sastra, seni rupa, seni tutur, dll. wayang terbuat dari boneka kayu, terutama sangat populer di wilayah Tanah pasundan, daerah penyebrangan terbentang luas dari Cirebon di sebelah timur sampai wilayah banten di sebelah barat. Ada beberapa pihak mengungkapkan, bahwa pertunjukan wayang bukan sekedar kesenian, karena mengandung lambang-lambang keramat.

\section{Metodelogi}

\subsection{Metode Pengambilan Data}

Metode pengambilan data yang digunakan dalam penelitian ini adalah pengumpulan data penunjang yang dilakukan dengan pengambilan data-data dari buku sejarah wayang, buku mengenai kebudayaan dan dari internet yang digunakan sebagai landasan. 


\subsection{Metode Pengembangan}

Dalam rancang bangun game fighting pewayangan bahuraksa arena menggunakan metode pengembangan Multimedia Development Life Cycle (MDLC). Menurut Sutopo (2003) metodologi ini terdiri dari 6 yaitu :

a. Konsep

Tahap ini adalah bagaimana merancang game fighting pewayangan bahuraksa arena

b. Desain

Tahap dimana pembuat atau pengembang project multimedia menjabarkan secara rinci apa yang akan dilakukan dan bagaimana project multimedia tersebut akan dibuat

c. Pengumpulan Bahan

Tahap dimana pengumpulan bahan yang sesuai dengan kebutuhan dilakukan

\section{d. Perakitan}

Tahap ini adalah proses pembuatan dari pengumpulan bahan.

e. Pengujian

Tahap ini adalah proses untuk menguji apakah pembuatan project ini mengalami masalah atau tidak.

f. Distribusi

Pada tahap ini, project yang telah selesai kemudian dilakukan pemaketan aplikasi. Dalam game ini akan di distribusikan ke dalam Store Smartphone, target utama pendistribusian ini adalah Play Store.

\section{Analisa dan Perancangan}

\subsection{Kebutuhan perakitan}

a. Kebutuhan Perangkat keras

- PC dengan Spesifikasi :

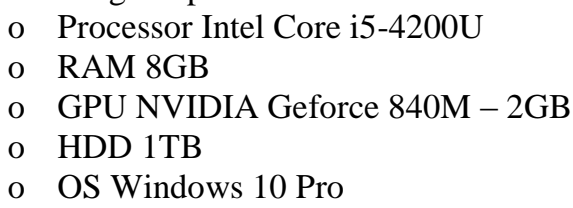

b. Kebutuhan Perangkat lunak pada PC

- Adobe Illustrator Creative Cloud 2015

- Adobe Photoshop Creative Cloud 2015

- Adobe Audition Creative Cloud 2015

- Unity 5.1

- Visual Studio community 2015

\subsection{Activity Diagram}

Activity diagram adalah penjabaran kegiatan atau aktivitas pemain atau user yang menjalankan game ini :

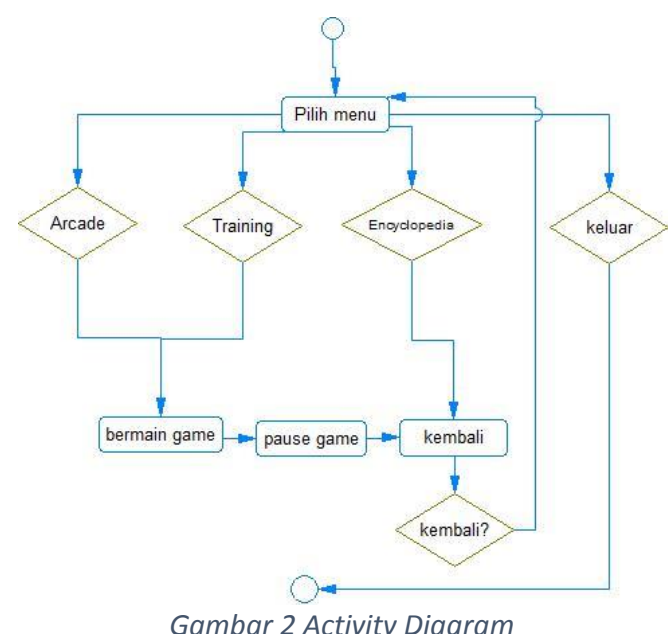

\subsection{Use Case}

Use Case adalah adalah rangkaian/uraian sekelompok yang saling terkait dan membentuk sistem secara teratur yang dilakukan atau diawasi oleh sebuah pengguna atau di sebut actor

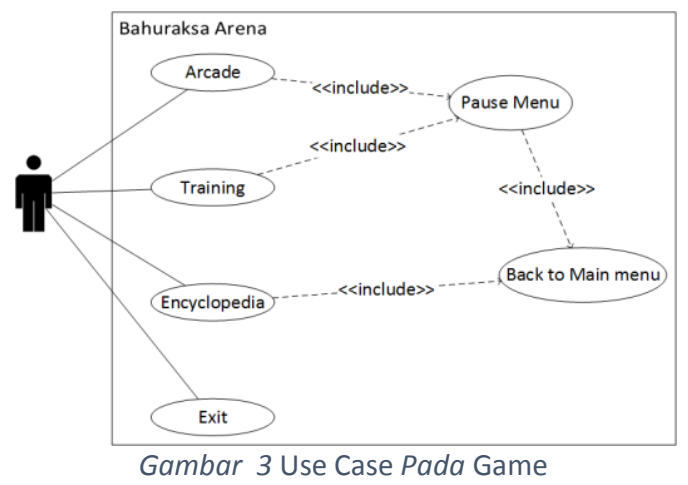

\subsection{Narasi}

Narasi cerita dalam game ini mengisahkan penyihir besar Bahuraksa yang marah dan sedih dengan Konflik antara pandawa dan kurawa mengakibatkan banyak korban berjatuhan termasuk anak semata wayang Bahuraksa, untuk mencegah banyaknya korban yang diakibatkan oleh dengan kedua pihak antara pandawa dan kurawa, Bahuraksa menciptakan dimensi khusus untuk pertarungan dan mengumpulkan pihak pandawa dan kurawa secara paksa. Bahuraksa menantang kedua pihak untuk bertarung sama lain dan harus bisa mengalahkan salah satu pihak kalau ingin keluar dari dimesi yang dia ciptakan.

\subsection{Metode N-Gram}

Metode yang diterapkan pada game ini adalah $\mathrm{N}$-Gram, metode $\mathrm{N}$-gram akan di terapkan pada musuh user/pemain, cara kerja metode ini adalah player memasukkan input serangan kemudian 
serangan itu akan di olah seperti pada flowchart dibawah ini :

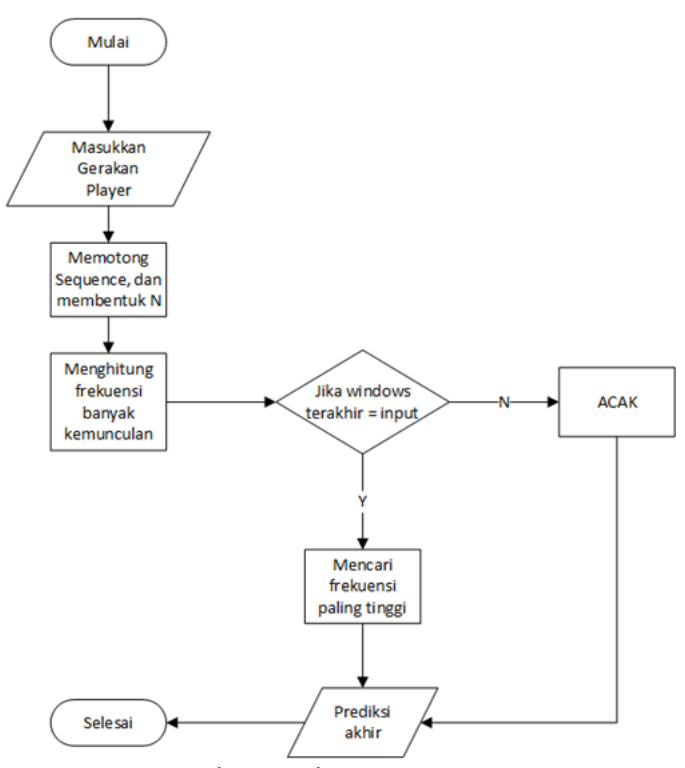

Gambar 4. Algoritma N-Gram

\subsection{Game rules}

Player akan melawan NPC yang sudah di beri pengetahuan atau istilahnya adalah Kecerdasan buatan dengan menggunakan metode N-Gram untuk membaca gerakan player kemudian memprediksi tindakan untuk melawan Player.

Sistem pertarungannya, player akan bertarung selama 100 detik dan setiap petarung akan memiliki health bar dan juga special bar yang tersedia penuh saat permainan.

a. Kondisi Menang :

- Health bar kecerdasan buatan habis

- Waktu habis dan persentase health bar Player lebih banyak dari kecerdasan buatan

b. Kondisi Kalah :

- Health bar Player habis

- Waktu habis dan prosentase Kecerdasan buatan lebih banyak dari Player.

Jika Player kalah, maka Player akan diberi kesempatan untuk melanjutkan lagi dengan hitungan sepuluh detik. Jika tidak lanjut maka permainan akan berakhir sehingga akan dikembalikan ke menu awal.

\section{Implementasi}

\subsection{Pembuatan Desain Game}

Tahap awal dalam implementasi game ini adalah bagaima mendesain sebuah game yang di konsep sebelumnya, cara pertama yang dilakukan adalah dengan mendesain sebuat user interface dengan menggunakan aplikasi Adobe Illustrator.

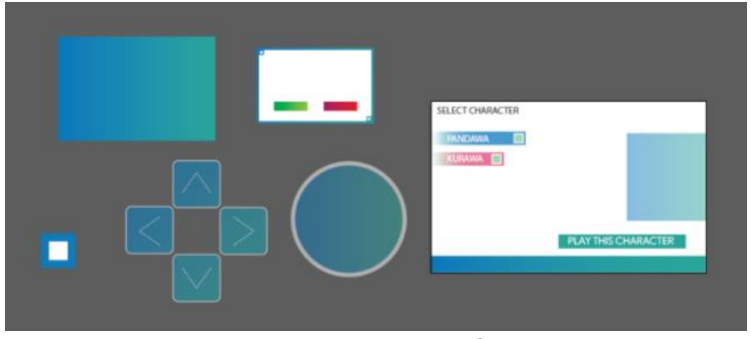

Gambar 5. User interface

Gambar 5 adalah user interface yang akan dimasukkan pada game, user interface adalah tampilan yang terdapat pada aplikasi ataupun game

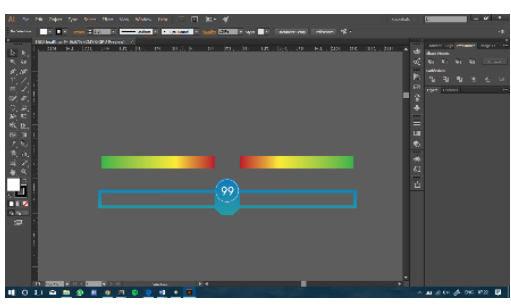

Gambar 6. HUD (Head-Up Display)

Gambar 6 adalah head-up display, yang dimana fungsinya adalah menampilkan status kondisi permainan pada user atau pemain.
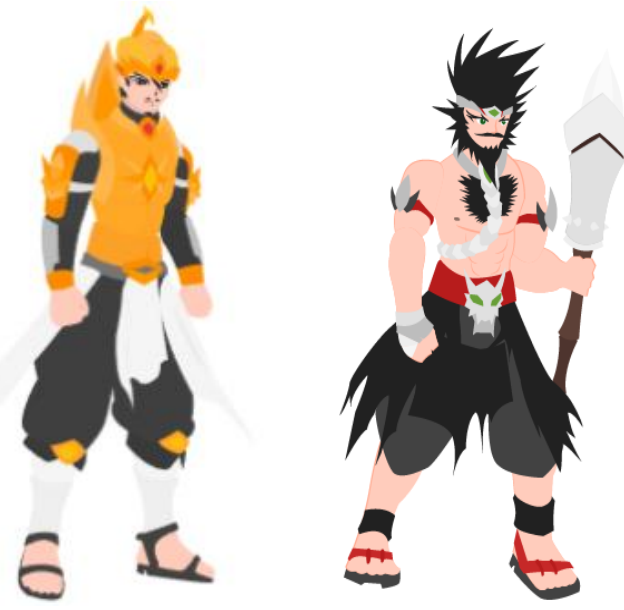

Gambar 7 Gambar Sprites Gatot dan Duryudana

Gambar 7 adalah Spriter karakter yang ada pada game yaitu Gatotkaca dan Duryudana, Spriter adalah object yang dapat dikendalikan atau bisa bergerak sesuai dengan keinginan pemain.

\subsection{Perakitan Game}

Hasil dari perakitan adalah seperti berikut : 

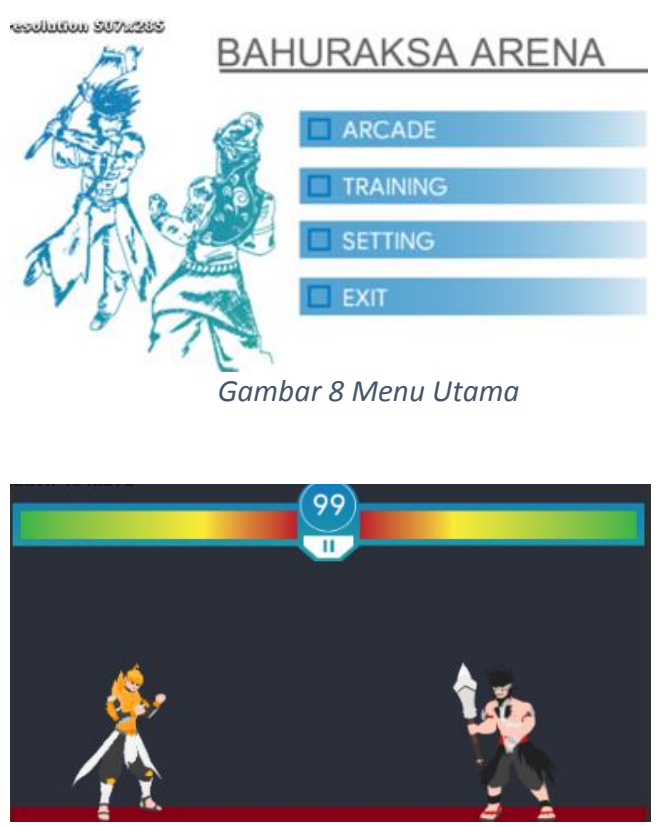

Gambar 9 Arena Pertarungan

\section{Pengujian dan Pembahasan}

\subsection{Pengujian Metode}

Untuk pengujian metode, akan dilakukan dengan cara mengawasi dan membandingkan tindakan dari kecerdasan buatan saat melawan pemain. Diberikan kesempatan sebanyak 2 kali sebanyak 15 tindakan yang sudah ditentukan, apakah tindakan pada kecerdasan buatan tersebut sama atau tidak dengan uji coba sebanyak 2 kali tersebut.

\section{a. Pengujian pertama :}

Tabel 1 Tabel Pengujian 1

\begin{tabular}{|l|l|l|}
\hline No. & \multicolumn{1}{|c|}{ Tindakan User } & \multicolumn{1}{|c|}{$\begin{array}{c}\text { Tindakan } \\
\text { Kecerdasan Buatan }\end{array}$} \\
\hline 1. & Diam & Diam \\
\hline 2. & $\begin{array}{l}\text { Bergerak Mundur } \\
\text { (tahan) }\end{array}$ & Diam \\
\hline 3. & $\begin{array}{l}\text { Bergerak Mundur } \\
\text { (tahan) }\end{array}$ & Bergerak Maju \\
\hline 4. & Memukul A & Menerima Damage \\
\hline 5. & Memukul A & Menerima Damage \\
\hline 6. & Memukul A & Bertahan \\
\hline 7. & Memukul A & Bertahan \\
\hline 8. & Memukul A & Bertahan \\
\hline 9. & Memukul B & Menerima Damage \\
\hline
\end{tabular}

\begin{tabular}{|l|l|l|}
\hline 10. & Melompat & Melompat \\
\hline 11. & $\begin{array}{l}\text { Bergerak Mundur } \\
\text { (tahan) }\end{array}$ & Bergerak Maju \\
\hline 12. & Diam & Memukul A \\
\hline 13. & Diam & Mundur \\
\hline 14. & Melompat & Melompat \\
\hline 15. & Bergerak Mundur & Diam \\
\hline
\end{tabular}

Tabel 2 Tabel Pengujian 2

\begin{tabular}{|l|l|l|}
\hline No. & Tindakan User & $\begin{array}{c}\text { Tindakan Kecerdasan } \\
\text { Buatan }\end{array}$ \\
\hline 1. & Diam & Diam \\
\hline 2 & $\begin{array}{l}\text { Bergerak } \\
\text { Mundur (tahan) }\end{array}$ & Maju \\
\hline 3. & $\begin{array}{l}\text { Bergerak } \\
\text { Mundur (tahan) }\end{array}$ & Memukul A \\
\hline 4. & Memukul A & Menerima Damage \\
\hline 5. & Memukul A & Bertahan \\
\hline 6. & Memukul A & Bertahan \\
\hline 7. & Memukul A & Menerima Damage \\
\hline 8. & Memukul A & Menerima Damage \\
\hline 9. & Memukul B & Bertahan \\
\hline 10 & Melompat & Melompat \\
\hline 11. & $\begin{array}{l}\text { Bergerak } \\
\text { Mundur (tahan) }\end{array}$ & Bergerak Maju \\
\hline 12. & Diam & Diam \\
\hline 13. & Diam & Maju \\
\hline 14. & Melompat & Melompat \\
\hline 15. & $\begin{array}{l}\text { Bergerak } \\
\text { Mundur }\end{array}$ & Diam \\
\hline
\end{tabular}

\subsection{Pembahasan}

Dari hasil Pengujian Metode mendapatkan hasil bahwa kecerdasan buatan menghasilkan pergerakan yang tidak di perkirakan oleh user/pemain, dari keseluruan tabel mendapatkan hasil yang berbeda. Bagaimana kecerdasan buatan tersebut mendapatkan hasil yang sangat berbeda diantara kedua tabel tersebut?

$\mathrm{N}$-gram adalah metode untuk memperkirakan prediksi, N-gram memiliki Sequence length dimana Sequence length ini adalah panjang urutan data Ngram yang digunakan dalam $\mathrm{N}$-gram, data $\mathrm{N}$-gram itu sendiri adalah inputan dari user atau pemain. Awalnya prediksi tidak akurat karena belum adanya data yang masuk, sehingga semua kemungkinan masih terbentuk, atau masih memiliki frekuensi yang kecil dan nilainya sama.

Hal itu membuat kecerdasan buatan menjadi pasif, sehingga untuk membuat lebih aktif perlu diberikan kondisi random, namun juga sudah 
ditentukan bagaimana frekuensi data yang di inputkan seperti Windows Size pada gambar 6.1

nilai maksimal akurasi adalah $100 \%$ untuk nilai maksimal, nilai 100 sampai dengan 50 adalah murni melakukan tindakan sesuai dengan mendapatkan $\mathrm{N}$-gram sedangkan di bawah 50 adalah titik dimana kecerdasan buatan melakukan tindakan secara acak.

\section{Kesimpulan}

Penerapan metode $\mathrm{N}$-gram dalam project ini untuk menghasilkan kecerdasan buatan yang aktif dan bertingkah laku yang berbeda pada setiap pertarungan pada game ini. Sehingga dapat menciptakan suasana game yang aktif karena user/pemain tidak bisa memprediksi apa yang akan dilakukan oleh kecerdasan buatan tersebut.

\section{Daftar Pustaka:}

Arifin, F., (2013): Implementasi Metode N-Gram pada pembuatan Game Fighting Madura berbasis Android OS Mobile, Jurnal Sarjana Teknik Informatika Vol. 1, No. 1, 08 Juli 2015.

AI Laili, C.F., (2014): Rancang Bangun Game Third Person Shooter 3d Monster Boat Atack, Skripsi diterbitkan.

Davy, C., (2015): Pengertian Wayang Indonesia Beserta Jenis-Jenisnya, [Online] Tersedia: http://www.macammacambudayaindonesia.co $\mathrm{m} / 2015 / 07 /$ pengertian-wayang-indonesiabeserta.html [7 Januari 2016].

Drew, J., (2013): Creating N-Grams Using C\#, [Online]Tersedia:

http://www.codeproject.com/Articles/582095/ CreatingplusN-gramsplusUsingplusC

[16 April 2016].

Millington, I., (2009): Artificial Intelligence For Games, New York, Morgan Kaufmann Publisher.

Pendit, N. S., (2003): Mahabarata, Jakarta, Gramedia.

Suharian, E., (2013): Pembuatan Game 2D

Basket Warrior Menggunakan Framework Orthello Dengan Unity Engine Untuk Platform Android, Jurnal Ilmiah MATRIK Vol. 10, No. 1, 06 Juli 2015 